\title{
sciendo
}

\section{Strategic Management in SMEs and Its Significance for Enhancing the Competitiveness in the V4 Countries - A Comparative Analysis}

\author{
Beata GAVUROVA \\ Faculty of Mining, Ecology, Process Control and Geotechnologies, Technical University of \\ Košice, Slovak Republic \\ beata.gavurova@tuke.sk
}

Martin CEPEL

Faculty of Economics and Business, Pan-European University in Bratislava, Slovak Republic

Jaroslav BELAS

Faculty of Management and Economics, Tomas Bata University in Zlin, Zlin, Czech Republic

Jan DVORSKY

Faculty of Management and Economics, Tomas Bata University in Zlin, Zlin, Czech Republic

\begin{abstract}
The study's main aim is to determine how the entrepreneurs in SMEs of the Visegrad Group (V4) perceive the strategic management process and how they manage strategic risks within it. The study also focuses on how a perception of examined determinants differs depending on business duration, management education and sex. The research was performed from 9/2019 to 4/2020 in the $V 4$ countries by means of online questionnaire. The findings were interesting. SMEs' business duration is a significant factor in evaluating the total structure of entrepreneurs' attitudes to the following fact: firm's strategic management is inevitable for corporate governance. Both SMEs' business duration and educational attainment are significant factors in evaluating the total structure of entrepreneurs' attitudes to the following fact: implementation of strategic management is required for day-to-day operations of a business. However, SMEs' business duration, management education and sex do not influence managers' attitudes to strategic management and strategic business risks. The results provide a valuable platform for the creators of national and regional strategic and development plans. Similarly, the results enable a creation of national and international benchmarking indicators in this area that would allow an improvement of the business environment and a creation of risk management systems, which are inevitable for SMEs.
\end{abstract}

Keywords: small and medium-sized enterprises (SMEs), strategic management, strategic risks, competitiveness, risk management system.

Please cite the article as follows: Gavurova, B., Cepel, M., Belas, J. and Dvorsky, J. (2020), "Strategic Management in SMEs and Its Significance for Enhancing the Competitiveness in the V4 Countries -A Comparative Analysis", Management \& Marketing. Challenges for the Knowledge Society, Vol. 15, No. 4, pp. 557-569, DOI: 10.2478/mmcks-2020-0032. 


\section{Introduction}

Dynamic changes in the entrepreneurial environment, globalisation processes and global epidemiological risks increase an interest in strategic management of the companies and a composition of crisis scenarios. New and fast-growing companies modify the traditional business models that have to adapt in rapidly changing conditions. These models are especially influenced by new technologies, demographic changes and competitive environments (Ik \& Azeez, 2020). Strategic management and strategic scenarios represent the basis of SMEs' management and existence, similarly as in large enterprises. Complexity of a competitive market requires a high level of flexibility and innovative development from SMEs (Subic, 2010). Innovative development in SMEs is more complicated than a level of flexibility, which is higher as opposed to large enterprises (Belas et al. 2020; Srovnalíková et al. 2020). This is related to strategic risks that may either disrupt a corporate strategy, or improve business performance. Strategic management enables an effective management of internal processes in a company, improves financial processes, supplier - customer relationships, outsourcing activities and adjusts adequate evaluation systems (Ajaz Khan et al. 2019; Šumpíková \& Durčeková, 2019). Strategic risk management requires knowledge of processes, such as identification, monitoring, information acquisition of new trends and important changes that influence SMEs' competitive advantage, its position on the market and its long-term performance (Novák Sedláčková et al. 2019). Knowledge of strategic management processes and active management of strategic risks enable companies to prepare themselves in good time and respond to any crisis (Dvorský et al. 2019). Successful companies compose their own crisis programs, use risk management systems via simulations and appropriate models and methods that are based on forecasting and scenario writing (Matijová et al. 2019; Megyesiova and Lieskovska, 2018) or new leadership models (Dima, Ghinea, 2016). Strategic management process changes depending on a company size, but also managers and senior management. In recent years, the business strategy template has been changing, while a formal strategy does not dominate anymore. It is probably related to a business strategy duration that has been significantly shortened. These consequential facts motivated authors to perform this research, which focuses on a perception of strategic management processes and strategic risk management in SMEs.

\section{Literature Review}

Many research studies examine the determinants of strategic management and its influence on process and output indicators of companies (Ivanova et al., 2019; Tacogliu et al., 2019; Oladimeji \& Udosen, 2019). The studies are considerably heterogeneous; however, they provide a valuable comparative platform. For instance, Bingöl et al. (2017) examine in the study an influence of strategic management tools on a firm's performance. As the authors suggest, the changes in strategic management are a consequence of the changes in the markets, from regional to international and from local to national. Consequently, competitiveness increases and the significance of strategic management tools are as well examined. In the study, the authors examine in detail the determinants' influence on the selection of strategic management tools and an impact of the extent to which the usage of tools has on a firm's performance. Milshina and Vishnevskiy (2017) dealt with the forecasting processes in SMEs. 
These authors consider innovations as very important aspects for SMEs' development. Thus, they focus on a research of tools that would develop innovations in SMEs. Similarly, the forecasting processes are considered as the most effective method for strategic planning by this team of authors. Successful strategic management requires forecasting processes that enable a possibility to set the targets, and also to estimate the potential consequences of developing new technologies, products and services. In conclusion, the authors state that it is important to build an innovative strategy, which is based on a firm's forecasting. Miladi (2014) emphasizes an importance of a leader in SMEs' management. Also, the author analyses the leader's influence on organizational culture that is a significant part of strategic management. The study aims at identifying the determinants of organizational culture development in SMEs that is considered as an important aspect of strategic management. The research was performed by means of a questionnaire in 120 SMEs in Tunisia. The author recognizes as the main finding the following: experiences and management training methods in SMEs represent the most considerable factors that influence organizational culture.

Pasanen (2011) examines a satisfaction with strategic techniques and tools in SMEs. The author notes an absence of relevant studies on usability of these tools in SMEs. Consequently, the author performed an empirical research among 143 SMEs in Finland that operate in the manufacturing sector and the service sector. The analysis results show that a satisfaction with usability of strategic management tools differs in SMEs from that in large enterprises.

Also, considerable differences were evident among SMEs in the manufacturing sector and the service sector. The study has numerous implications that focus on a performance in SMEs. Jones \& Sisay (2014) consider strategic orientation as a significant aspect in strategic management. Their study aim was to evaluate the strategic orientation in SMEs. The authors were especially motivated by an increasing interest in obtaining new knowledge of strategic behaviour in SMEs. Various strategic orientations in the companies result in higher or lower profitability, as well as in a company growth. The benefit of this study is a formation of a conceptual model that includes several strategic typologies for SMEs. The study also includes many proposals for SMEs' development in the future and subsequently, it offers many policy implications.

Research of strategic frameworks and strategic analyses has been subject of numerous studies for more than 20 years. Also, the concepts have been changing during this development that is also confirmed by Stonehouse and Pemberton (2002). The authors' research focuses on 159 SMEs in the manufacturing and the service sectors. The study aim was to examine the differences between theoretical concepts and practice in strategic planning. Even the examined firms confirmed an existence of the forms of strategic planning, there was found less evidence of strategic thinking. The study also offers some ideas of deeper research of the determinants that influence more suitable use of theoretical concepts of strategic management in practice.

Similarly, Avila and Preiss (2015) highlight an importance of strategic management in SMEs considering a difficult competitive environment and globalisation processes. These authors criticize the use of strategic management processes in the Mexican SMEs, as well as a low flexibility of SMEs in achieving a competitive advantage. The authors recommend increasing flexibility by hiring strategic management consultants. Bembenek and Kowalska (2016) notice an importance of SMEs' development by means of clusters. Even though the 
clusters' limitations are not clear, the clusters are significant for a concentration of research and development subjects, institutions that support entrepreneurship and firms which are all interconnected. These firms may operate in the same or in similar sectors, co-operate with each other and/or even compete with each other. Hence, more favourable conditions are created for developing business and innovations. Cluster coordinators, whose specific tasks are very important, create optimal conditions for cluster members. Also, effective cluster coordination increases its competitiveness.

Edun and Wei (2011) examine a significance of knowledge management and innovation for SMEs' competitiveness. As the authors state, the African SMEs faced many issues in relation to innovative products as opposed to American and European firms. The authors emphasize an inevitability of recasting the business and the technological models in SMEs in order to find new ways of knowledge and innovation management. As the authors suggest, management of innovations and innovation performance in SMEs may increase SMEs' competitiveness, as also proved by the analysis of Dinca et al. (2019). The study has numerous implications for policy creators. Verbano and Crema (2014) examine an interconnection of technology innovation strategy, intellectual capital and technology innovation performance in SMEs within strategic management. The study results support a creation of a system for measuring an intellectual capital in SMEs and an importance of its individual components in increasing technology innovation performance.

Similarly, Aricioglu (2020) deals with strategic management in SMEs in terms of clusters. The author evaluates clusters' significance by means of the theoretical basis. These clusters are considered as one of the effective tools of a competitiveness increase in global economy. The clusters' significance will increase in the process of digitalization of the industry.

Entrialgo et al. (2000) examine a relation between an entrepreneurship and strategic management in terms of content and process. The authors analyse an impact of competitive strategy, flexibility, analysis procedures, time horizon, planning and controlling aspects on a business. Their research was carried out on a sample of 233 Spanish SMEs. The results show positive relationship between entrepreneurship and analysis, flexibility, locus of planning, control and strategy based on differentiation.

All above-mentioned studies present evident trends in strategic management and a strong orientation of strategic processes to output metrics, such as a firm's performance and innovations. Also, human resources that influence process of strategic management in all of its phases represent a very important aspect. The knowledge of managers' attitudes to the individual aspects of strategic management, as well as the knowledge of what determines the changes in the attitudes that focus on firms' strategic management is an important factor in the formation of strategic management processes. However, studies that would follow these differentiation aspects of a research are missing. The reason may be a methodological complexity of researches and their difficulty in data collection, which are mostly realized via questionnaire, and/or interview method. The above-mentioned facts represent a primary motivation to realize this research that is presented in the following chapters.

\section{Methodology}

The main aim of the study was to determine how entrepreneurs in SMEs of the Visegrad Group (V4) perceive strategic management process and how they manage the strategic 
risks. Also, the study focuses on a different perception of examined determinants, which depend on business duration, management education and sex.

Data collection in SMEs was realized by means of online questionnaire. The questionnaire could have been filled in by the owner or senior manager of a particular SME (hereinafter 'respondent'). The data collection was carried out from 9/2019 to 4/2020 in V4 countries (the Czech Republic - CR, Slovakia - SR, Poland - PL, Hungary - H). Random selection was used to address 8,250 SMEs in CR; 10,100 SMEs in SR; 7,680 SMEs in PL and 8,750 SMEs in HU. Information about SMEs was obtained from the CRIBIS database (CR, SR); from the database of the Central Statistical Office of Poland (PL) and from the database of the Chamber of Commerce and Industry in Budapest $(\mathrm{H})$.

The approach for creating a random sample of respondents was: i. definition of the basic set of respondents according to the selected criterion (SMEs up to 249 employees); ii. assignment of a serial number; iii. generation of random numbers using the mathematical function "Randbetween"; iv. assignment of respondents to randomly generated numbers; $\mathrm{v}$. finding out the contacts. In the first phase, the SMEs were addressed via email with a request to fill in an online questionnaire. In the second phase, the SMEs were contacted by telephone with a request to fill in a questionnaire. The above approach was used for each country. The average questionnaire response rate was as follows: CR $-3.6 \%$; SR $-5.5 \%$; PL $-4.7 \%$; $\mathrm{HU}-4.6 \%$.

The questionnaire consisted of 77 questions. The first part included the basic characteristics of respondents and SMEs. Strategic management in SMEs was the main purpose of this study. The respondent could select from the following answers: A1 Completely Agree; A2 - Agree; A3 - Neutral; A4 - Disagree; A5 - Completely Disagree. The questionnaire was filled in by 1620 respondents. The number of correctly filled in questionnaires (hereinafter referred to as the sample) was represented by 1,585 (97.5\%) respondents. The number of incorrectly filled in questionnaires was represented by 35 (2.5\%) respondents (e.g., not consistent attitudes of the respondent on selected statements). The study focuses on the following statements available in the questionnaire in order to fulfil its main aim:

STR1: Strategic management in a company is an integral part of corporate governance.

STR2: Strategic management is implemented in everyday life in our company and achieved through action plans and programs.

STR3: Proper strategic management improves the competitive ability of our company and its stability in domestic and foreign markets.

STR4: Our company regularly monitors, evaluates and manages strategic risks.

The following statistical hypotheses were formulated:

H1: There are no statistically significant differences among respondents in a total structure of the attitudes to the statements of strategic risk (STR1 - H_STR1; STR2 H_STR2; STR3 - H_STR3; STR4 - H_STR4) in terms of business duration of the company (H1A); the educational attainment (H1B) and sex of the entrepreneur (H1C).

H2: There are no statistically significant differences among respondents in 'Agree' responses $(\mathrm{A} 1+\mathrm{A} 2)$ to the statements of strategic risk (STR1 - H_STR1; STR2 - H_STR2; STR3 - H_STR3; STR4 - H_STR4) in terms of business duration of the company (H2A); the educational attainment (H2B) and sex of the entrepreneur (H2C). 
The statistical software, SPSS Statistics, made all calculations in the research.

\section{Findings}

The structure of a total number of respondents $(\mathrm{n}=1,585)$ by country is as follows: 454 (28.6\%) respondents from CR, 368 (23.2\%) respondents from STR, 364 (23.0\%) respondents from PL, 399 (25.2\%) respondents from HU.

Table 1 provides an overview of the remaining questions related to the respondents' characteristics.

Table 1. Structure of respondents according to selected demographic characteristics

\begin{tabular}{|c|c|c|c|c|c|}
\hline \multicolumn{2}{|l|}{ Company Size } & \multicolumn{2}{|c|}{$\begin{array}{l}\text { Business Period of the } \\
\text { Company }(\%)\end{array}$} & \multicolumn{2}{|l|}{ Line of Business } \\
\hline Micro-Enterprise & $61.6 \%$ & Below 3 years & $9.2 \%$ & Production & $17.0 \%$ \\
\hline Small Enterprise & $18.8 \%$ & $3-5$ years & $8.8 \%$ & Trade & $16.3 \%$ \\
\hline $\begin{array}{l}\text { Medium-Sized } \\
\text { Enterprise }\end{array}$ & $19.6 \%$ & $5-10$ years & $15.8 \%$ & Civil Engineering & $9.8 \%$ \\
\hline \multicolumn{2}{|l|}{ Undertaking } & $\begin{array}{l}\text { More than } 10 \\
\text { years }\end{array}$ & $66.2 \%$ & Transport & $3.3 \%$ \\
\hline $\begin{array}{l}\text { Self-Employed } \\
\text { Person }\end{array}$ & $30.2 \%$ & \multirow{2}{*}{\multicolumn{2}{|c|}{ Education \& Line of Business }} & Agriculture & $6.1 \%$ \\
\hline LLC & $56.7 \%$ & & & Tourism & $2.8 \%$ \\
\hline PLLC & $6.0 \%$ & Related & $43.3 \%$ & Services & $35.3 \%$ \\
\hline Other type & $7.1 \%$ & \multirow{2}{*}{$\begin{array}{l}\text { To Some Extent } \\
\text { Related }\end{array}$} & \multirow{2}{*}{$32.6 \%$} & \multirow{2}{*}{ Other Lines } & \multirow{2}{*}{$9.4 \%$} \\
\hline \multirow{2}{*}{\multicolumn{2}{|c|}{ The Educational Attainment }} & & & & \\
\hline & & Not Related & $24.1 \%$ & \multicolumn{2}{|l|}{ Sex } \\
\hline \multirow{2}{*}{$\begin{array}{l}\text { Secondary } \\
\text { Education }\end{array}$} & \multirow{2}{*}{$28.2 \%$} & \multirow{2}{*}{\multicolumn{2}{|c|}{ Age }} & Male & $68.2 \%$ \\
\hline & & & & Female & $31.8 \%$ \\
\hline \multirow{2}{*}{$\begin{array}{l}\text { Bachelor's Degree } \\
\text { (Bc.) }\end{array}$} & \multirow[b]{2}{*}{$14.3 \%$} & Age till 35 years & $19.7 \%$ & \multicolumn{2}{|l|}{ Work Position } \\
\hline & & $\begin{array}{l}\text { Age from } 36-45 \\
\text { years }\end{array}$ & $30.0 \%$ & \multirow[b]{2}{*}{ Owner } & \multirow[b]{2}{*}{$26.6 \%$} \\
\hline $\begin{array}{l}\text { Engineer's Degree / } \\
\text { Master's Degree } \\
\text { (Ing./Mgr.) }\end{array}$ & $50.0 \%$ & $\begin{array}{l}\text { Age from } 46-55 \\
\text { years }\end{array}$ & $28.5 \%$ & & \\
\hline $\begin{array}{l}\text { Doctoral Degree } \\
\text { (Ph.D.) }\end{array}$ & $7.5 \%$ & Age above 56 years & $21.8 \%$ & Senior manager & $73.4 \%$ \\
\hline
\end{tabular}

Source: Authors' development.

The structure of the respondents' attitudes $(\mathrm{n}=1,585$; statements of strategic risk - STR1, STR2, STR3 and STR4) is provided in Table 2.

Table 2. Evaluation of strategic risk statements by respondents according to business duration

\begin{tabular}{|l|l|l|l|l|}
\hline \multicolumn{1}{|c|}{ STR } & \multicolumn{1}{c|}{ STR1 } & \multicolumn{1}{c|}{ STR2 } & \multicolumn{1}{c|}{ STR3 } & \multicolumn{1}{c|}{ STR4 } \\
\hline A1 (\%) & $571(36.0)$ & $272(17.2)$ & $414(26.1)$ & $234(14.7)$ \\
\hline A2 (\%) & $663(41.8)$ & $588(37.1)$ & $632(39.9)$ & $549(34.7)$ \\
\hline A3 (\%) & $257(16.2)$ & $499(31.5)$ & $385(24.3)$ & $479(30.2)$ \\
\hline A4 (\%) & $65(4.1)$ & $161(10.1)$ & $113(7.1)$ & $224(14.1)$ \\
\hline A5 (\%) & $29(1.9)$ & $65(4.1)$ & $41(2.6)$ & $99(6.3)$ \\
\hline
\end{tabular}




\section{Comparison of attitudes according to business duration of SME}

The findings show that there are 536 (33.8\%) SMEs with business duration up to 10 years and 1,049 (66.2\%) SMEs with business duration above 10 years out of a total number of respondents $(n=1,585 ; 100 \%)$. Table 3 shows a number of respondents who responded to the statements of strategic management according to SMEs' business duration.

Table 3. Evaluation of strategic risk statements by respondents according to business duration

\begin{tabular}{|c|c|c|c|c|c|}
\hline STR1 & $\geq 10$ years & $<10$ years & STR2 & $\geq 10$ years & $<10$ years \\
\hline A1 (\%) & $199(37.1)$ & $372(35.5)$ & A1 (\%) & $107(20.0)$ & $165(15.7)$ \\
\hline A2 (\%) & 214 (39.9) & 449 (42.8) & A2 (\%) & $184(34.3)$ & $404(38.5)$ \\
\hline A3 (\%) & $78(14.6)$ & $179(17.1)$ & A3 (\%) & $158(39.5)$ & $341(32.5)$ \\
\hline A4 (\%) & $30(5.6)$ & $35(3.3)$ & A4 (\%) & $57(10.6)$ & $104(9.9)$ \\
\hline A5 (\%) & $15(2.8)$ & $14(1.3)$ & A5 (\%) & $30(5.6)$ & $35(3.4)$ \\
\hline $\begin{array}{l}\text { Chi- square test } \\
\text { (P-value) }\end{array}$ & \multicolumn{2}{|l|}{$10.930(0.027)$} & $\begin{array}{l}\text { Chi- square test } \\
\text { (P-value) }\end{array}$ & \multicolumn{2}{|l|}{$11.015(0.026)$} \\
\hline STR3 & $\geq 10$ years & $<10$ years & STR4 & $\geq 10$ years & $<10$ years \\
\hline $\mathrm{A} 1(\%)$ & $150(28.0)$ & $264(25.2)$ & A1 (\%) & $93(17.3)$ & $141(13.4)$ \\
\hline A2 (\%) & $212(39.5)$ & $420(40.0)$ & A2 (\%) & $176(32.8)$ & $373(35.6)$ \\
\hline A3 (\%) & $115(21.5)$ & $270(25.7)$ & A3 (\%) & $156(29.1)$ & 323 (30.8) \\
\hline $\mathrm{A} 4(\%)$ & $43(8.0)$ & $70(6.7)$ & $\mathrm{A} 4(\%)$ & $70(13.1)$ & $154(14.7)$ \\
\hline A5 (\%) & $16(3.0)$ & $25(2.4)$ & A5 (\%) & $41(7.7)$ & $58(5.5)$ \\
\hline $\begin{array}{l}\text { Chi- square test } \\
\text { (P-value) }\end{array}$ & \multicolumn{2}{|l|}{$5.182(0.269)$} & $\begin{array}{l}\text { Chi- square test } \\
\text { (P-value) }\end{array}$ & \multicolumn{2}{|l|}{$7.978(0.092)$} \\
\hline
\end{tabular}

Source: Authors' development.

The results in Table 3 confirmed statistically significant differences in a total structure of respondents' attitudes to the statements STR1 ( $\mathrm{p}$ - value $=0.027$ ) and STR2 ( $\mathrm{p}$ - value $=$ 0.026 ) among enterprises up to 10 years and above 10 years during their business period. However, no statistically significant differences were confirmed among respondents in a total structure of attitudes to STR3 and STR4 in terms of business duration in a business environment (STR3: -value $=0.269$; STR4: $\mathrm{p}$-value $=0.092$ ). These hypotheses H1A_STR1 and H1A_STR2 were rejected, and these hypotheses H1A_STR3 and H1A_STR4 were confirmed. Table 4 presents the comparison results in terms of 'Agree' responses given by respondents $(\mathrm{A} 1+\mathrm{A} 2)$ to the statements of strategic risk according to business duration in SMEs.

Table 4. A comparison of 'Agree' responses of respondents to strategic risk statements according to business duration

\begin{tabular}{|c|c|c|c|c|c|}
\hline STR1 & $\geq 10$ years & $<10$ years & STR2 & $\geq 10$ years & $<10$ years \\
\hline $\mathrm{A} 1+\mathrm{A} 2[\%]$ & 413 (77.1) & $821(78.3)$ & $\mathrm{A} 1+\mathrm{A} 2[\%]$ & $291(54.3)$ & $569(54.2)$ \\
\hline $\begin{array}{l}\text { Z- test } \\
\text { (P-value) }\end{array}$ & \multicolumn{2}{|l|}{$-0.550(0.582)$} & $\begin{array}{l}\text { Z- test (P- } \\
\text { value) }\end{array}$ & \multicolumn{2}{|l|}{$0.019(0.984)$} \\
\hline STR3 & $\geq 10$ years & $<10$ years & STR4 & $\geq 10$ years & $<10$ years \\
\hline $\mathrm{A} 1+\mathrm{A} 2$ [\%] & $362(67.5)$ & $684(65.2)$ & $\mathrm{A} 1+\mathrm{A} 2[\%]$ & $269(50.2)$ & $514(49.0)$ \\
\hline $\begin{array}{l}\text { Z- test } \\
\text { (P-value) }\end{array}$ & \multicolumn{2}{|l|}{$0.927(0.352)$} & $\begin{array}{l}\text { Z- test (P- } \\
\text { value) }\end{array}$ & \multicolumn{2}{|l|}{$0.447(0.653)$} \\
\hline
\end{tabular}

Source: Authors' development.

The results in Table 4 did not confirm any statistically significant differences in 'Agree' responses of respondents to the strategic risk statements according to business duration of 
the company (p- values > 0.05). Thus, these hypotheses H2A_STR1; H2A_STR2 H2A_STR3 and H2A_STR4 were confirmed.

\section{Comparison of attitudes according to educational attainment of respondents}

The findings show that there are $446(28.2 \%)$ respondents without university degree and $1,139(71.9 \%)$ respondents with university degree out of a total number of respondents $(\mathrm{n}=1,585 ; 100 \%)$. Table 5 demonstrates the number of respondents answering the strategic risk statements according to the educational attainment.

Table 5. Evaluation of strategic risk statements by respondents according to management education

\begin{tabular}{|l|l|l|l|l|l|}
\hline \multicolumn{1}{|c|}{ STR1 } & \multicolumn{1}{c|}{ WUG } & \multicolumn{1}{c|}{ UG } & \multicolumn{1}{c|}{ STR2 } & \multicolumn{1}{c|}{ WUG } & \multicolumn{1}{c|}{ UG } \\
\hline A1 (\%) & $139(31.2)$ & $432(37.9)$ & A1 (\%) & $68(15.3)$ & $204(17.9)$ \\
\hline A2 (\%) & $199(44.6)$ & $464(40.8)$ & A2 (\%) & $165(37.0)$ & $423(37.1)$ \\
\hline A3 (\%) & $85(19.1)$ & $172(15.1)$ & A3 (\%) & $162(36.3)$ & $337(29.6)$ \\
\hline A4 (\%) & $17(3.8)$ & $48(4.2)$ & A4 (\%) & $33(7.4)$ & $128(11.3)$ \\
\hline A5 (\%) & $6(1.3)$ & $23(2.0)$ & A5 (\%) & $18(4.0)$ & $47(4.1)$ \\
\hline $\begin{array}{l}\text { Chi-square test } \\
\text { (P-value) }\end{array}$ & $9.240(0.055)$ & $\begin{array}{l}\text { Chi-square test } \\
\text { (P-value) }\end{array}$ & $10.601(0.031)$ \\
\hline STR3 & WUG & UG & STR4 & WUG & UG \\
\hline A1 (\%) & $105(23.6)$ & $309(27.1)$ & A1 (\%) & $64(14.3)$ & $170(14.9)$ \\
\hline A2 (\%) & $178(39.9)$ & $454(39.9)$ & A2 (\%) & $165(37.0)$ & $384(33.7)$ \\
\hline A3 (\%) & $129(28.9)$ & $256(22.5)$ & A3 (\%) & $122(27.3)$ & $357(31.3)$ \\
\hline A4 (\%) & $26(5.8)$ & $87(7.6)$ & A4 (\%) & $63(14.2)$ & $161(14.2)$ \\
\hline A5 (\%) & $8(1.8)$ & $33(2.9)$ & A5 (\%) & $32(7.2)$ & $67(5.9)$ \\
\hline $\begin{array}{l}\text { Chi-square test } \\
\text { (P-value) }\end{array}$ & $10.044(0.040)$ & $\begin{array}{l}\text { Chi-square test } \\
\text { (P-value) }\end{array}$ & $3.613(0.461)$ & \\
\hline
\end{tabular}

Note: WUG - Without university degree; UG - University degree (Bachelor's, Master's and Doctoral degree). Source: Authors' development.

The results in Table 5 confirmed statistically significant differences in a total structure of respondents' attitudes to the statements STR3 ( $\mathrm{p}$-value $=0.031$ ) and STR3 ( $\mathrm{p}$-value $=$ 0.040 ) who were without university degree and with university degree. However, no statistically significant differences in a total structure of attitudes were confirmed to the statements STR1 and STR4 according to the educational attainment (STR1: p-value $=0.055$; STR4: -value $=0.461$ ). These hypotheses H1A_STR2 and H1A_STR3 were rejected, and these hypotheses H1A_STR1 and H1A_STR4 were confirmed. Table 6 presents the comparison results of 'Agree' responses given by respondents $(\mathrm{A} 1+\mathrm{A} 2)$ to strategic risk statements according to the educational attainment.

Table 6. A comparison of 'Agree' responses of respondents to strategic risk statements according to management education

\begin{tabular}{|l|l|l|l|l|l|}
\hline STR1 & WUG & UG & STR2 & WUG & UG \\
\hline A1+A2 [\%] & $338(75.8)$ & $869(78.7)$ & A1+A2 [\%] & $233(52.2)$ & $627(55.0)$ \\
\hline $\begin{array}{l}\text { Z- test } \\
\text { (P- value) }\end{array}$ & \multicolumn{2}{|l|}{$-0.214(0.834)$} & $\begin{array}{l}\text { Z- test } \\
\text { (P-value) }\end{array}$ & \multicolumn{2}{|l|}{$-1.008(0.313)$} \\
\hline STR3 & WUG & UG & STR4 & WUG & UG \\
\hline A1+A2 [\%] & $283(63.5)$ & $763(67.0)$ & A1+A2 [\%] & $229(51.3)$ & $554(48.6)$ \\
\hline $\begin{array}{l}\text { Z- test } \\
\text { (P- value) }\end{array}$ & $-1.336(0.180)$ & $\begin{array}{l}\text { Z- test } \\
\text { (P-value) }\end{array}$ & $0.969(0.332)$ & \\
\hline
\end{tabular}

Source: Authors' development. 
The results in Table 6 did not confirm any statistically significant differences in 'Agree' responses given by respondents to strategic risk statements ( $p$ - values $>0.05$ ) according to the educational attainment. These hypotheses H2B_STR1; H2B_STR2 H2B_STR3 and H2B_STR4 were confirmed.

\section{Comparison of attitudes according to sex of respondents}

The findings show that there are 1,081 (68.2\%) men and $504(31.8 \%)$ women out of a total number of respondents $(\mathrm{n}=1,585 ; 100 \%)$. Table 7 provides a number of respondents who responded to the statements of strategic risk according to the respondents' sex.

Table 7. Evaluation of strategic risk statements by respondents according to sex

\begin{tabular}{|l|l|l|l|l|l|}
\hline \multicolumn{1}{|c|}{ STR1 } & \multicolumn{1}{c|}{ Men } & \multicolumn{1}{c|}{ Women } & \multicolumn{1}{c|}{ STR2 } & \multicolumn{1}{c|}{ Men } & \multicolumn{1}{c|}{ Women } \\
\hline A1 (\%) & $375(34.7)$ & $196(38.9)$ & A1 (\%) & $174(16.1)$ & $98(19.4)$ \\
\hline A2 (\%) & $460(42.5)$ & $203(40.3)$ & A2 (\%) & $398(36.8)$ & $190(37.7)$ \\
\hline A3 (\%) & $179(16.6)$ & $78(15.5)$ & A3 (\%) & $342(31.6)$ & $157(31.2)$ \\
\hline A4 (\%) & $46(4.3)$ & $19(3.7)$ & A4 (\%) & $119(11.0)$ & $42(8.3)$ \\
\hline A5 (\%) & $21(1.9)$ & $8(1.6)$ & A5 \%) & $48(4.5)$ & $17(3.4)$ \\
\hline $\begin{array}{l}\text { Chi-square test } \\
\text { (P- value) }\end{array}$ & $2.791(0.593)$ & $\begin{array}{l}\text { Chi- square test } \\
\text { (P- value) }\end{array}$ & $5.720(0.221)$ \\
\hline STR3 & Men & Women & STR4 & Men & Women \\
\hline A1 (\%) & $278(25.7)$ & $136(27.0)$ & A1 (\%) & $153(14.2)$ & $81(16.1)$ \\
\hline A2 (\%) & $430(39.8)$ & $202(40.1)$ & A2 (\%) & $382(35.3))$ & $167(33.1)$ \\
\hline A3 (\%) & $257(23.8)$ & $128(25.4)$ & A3 (\%) & $320(29.6)$ & $159(31.5)$ \\
\hline A4 (\%) & $88(8.1)$ & $25(5.0)$ & A4 (\%) & $158(14.6)$ & $66(13.1)$ \\
\hline A5 (\%) & $28(2.6)$ & $13(2.6)$ & A5 (\%) & $68(6.3)$ & $31(6.2)$ \\
\hline $\begin{array}{l}\text { Chi- square test } \\
\text { (P- value) }\end{array}$ & $5.468(0.242)$ & $\begin{array}{l}\text { Chi- square test } \\
\text { (P- value) }\end{array}$ & $2.342(0.673)$ & \\
\hline
\end{tabular}

Source: Authors' development.

However, no statistically significant differences among respondents in a total structure of attitudes to strategic risk statements (Table 7; p- values $>0.05$ ) according to sex were confirmed. These hypotheses H1C_STR1; H1C_STR2; H1C_STR3 and H1C_STR4 were confirmed. Table 8 shows the comparison results of 'Agree' responses given by respondents $(A 1+A 2)$ to strategic risk statements according to sex.

Table 8. A comparison of 'Agree' responses of respondents to strategic risk statements according to sex

\begin{tabular}{|l|l|l|l|l|l|}
\hline \multicolumn{1}{|c|}{ STR1 } & \multicolumn{1}{|c|}{ Men } & \multicolumn{1}{c|}{ Women } & \multicolumn{1}{c|}{ STR2 } & \multicolumn{1}{c|}{ Men } & \multicolumn{1}{c|}{ Women } \\
\hline A1+A2 [\%] & $835(77.2)$ & $399(79.2)$ & A1+A2 [\%] & $572(52.9)$ & $288(57.1)$ \\
\hline $\begin{array}{l}\text { Z- test } \\
\text { (P- value) }\end{array}$ & \multicolumn{2}{|l|}{$-0.859(0.390)$} & $\begin{array}{l}\text { Z- test } \\
\text { (P- value) }\end{array}$ & $-1.574(0.116)$ & \\
\hline STR3 & Men & Women & STR4 & Men & Women \\
\hline A1+A2 [\%] & $708(65.5)$ & $338(67.1)$ & A1+A2 [\%] & $535(49.5)$ & $248(49.2)$ \\
\hline $\begin{array}{l}\text { Z- test } \\
\text { (P- value) }\end{array}$ & $-0.614(0.542)$ & $\begin{array}{l}\text { Z- test } \\
\text { (P- value) }\end{array}$ & $0.106(0.912)$ & \\
\hline
\end{tabular}

Source: Authors' development. 
The results in Table 8 did not confirm any statistically significant differences in 'Agree' responses given by respondents to strategic risk statements according to sex (p-values > 0.05). These hypotheses H2C_STR1; H2C_STR2 H2C_STR3 and H2C_STR4 were confirmed.

\section{Conclusions}

The company's success highly depends on a high-quality and a thoughtful strategy. Strategic management represents the most important managerial activity and it creates a basis for the entire management in each firm. Its main role is to effectively change mission and scope of the company to desired results that provide prosperity and growth for the company. In recent years, an importance and a content of strategic management processes have been changing; also, there has been an increasing tendency for the management of strategic risks. Many research studies examine impacts of companies' strategic management processes on various sectors and macro-economic indicators. In strategic management, new methods, procedures and principles have been developed, while managers' attitudes to strategic management and their strategic thinking are very important for their effective usage. Consequently, the study focuses on a perception of how managers in SMEs in the V4 countries perceive strategic management. The research processes also analysed many differentiation perspectives, as the study aim was to determine if business duration, management education and sex have any influence on a different perception of an importance of strategic management processes in SMEs. The analysis results show that the educational attainment is a significant factor in evaluating a total structure of entrepreneurs' attitudes to the statement: properly set strategic management improves the company's competitiveness. Similarly, it was confirmed that SMEs' business duration and educational attainment are important factors in a total structure of entrepreneurs' attitudes when implementing strategic management in the company's everyday life. SMEs' business duration represents a considerable factor in evaluating a total structure of entrepreneurs' attitudes to the statement that the company's strategic management is an inevitable part of corporate governance. On the other hand, sex does not represent an important factor in the entrepreneurs' attitudes to the strategic management statements. Also, an impact of SMEs' business duration, education and sex on changes in the entrepreneurs' attitudes to the company's strategic management and strategic risks was not confirmed.

As the above findings show, the socio-economic determinants influence the strategic management in the enterprises. These may also have an impact on its implementation phases, the attitudes of entrepreneurs to perceive this process as a way of competitiveness increase in their company, and an elimination of the strategic risks. Obviously, it is not possible to generalize the results of this research with regard to a size of the research sample. However, the most important fact is that the socio-economic determinants will play a significant role in a success evaluation of the strategic management in a company in the future, and it is necessary to examine them in more details. Similarly, it will require an appropriate approach to more profound structured data. In the future, strong dynamics of a competitive environment, external environment factors that influence enterprises' flexibility and globalisation processes will create a new space for a formation of successful strategies and their implementation into the operation of the enterprises. It will probably require increased needs for the entrepreneurs' knowledge of the strategic management methods and will also put a pressure on the education system. The recent economic crisis and also the current COVID-19 pandemic create stronger economic pressures on the 
enterprises' operations. Thus, the strategic management processes and their research from a theoretical/methodological and also dimensional point of view form a new opinion on a successful operation of the enterprises and a creation of an effective economic system in each enterprise. The future research of this group of authors aims at examining a perception of the strategic management by managers within V4 countries depending on the sectors in the economy and on the enterprises' sizes. It may be assumed, based on the research, that the severity of the processes which take place in the enterprises in the individual sectors will influence a need to implement the strategic management and a different perception of its importance by entrepreneurs.

The study results provide a valuable information for the creators of strategic and development plans that focus on the development of a business environment, and also for strategic and crisis management specialists. Also, the research results support the creation of national and international benchmarking indicators in this area.

\section{Acknowledgment}

The research was supported by the Research and Development Agency GAAA under the contract No. 21/2020: 'Management, business risk and firm bankruptcy in the segment of SMEs'.

\section{References}

Agresti, A. (1992). A survey of exact inference for contingency tables. Statistical Science, 7(1), 131-153. doi:10.1214/ss/1177011454.

Andriessen, D. (2006). On the metaphorical nature of intellectual capital: a textual analysis. Journal of Intellectual Capital, 7(1), 93-110.

Aldag, R.J., \& Stearns, T.M. (1991). Management (2nd ed.). Cincinnati, OH: South-Western Publishing.

Arıcıoğlu, M. A. \& Yiğitol, B. (2020). Strategic Management in SMEs in the Context of Clustering. Challenges and Opportunities for SMEs in Industry 4.0,22. doi: 10.4018/978-1-7998-2577-7.ch011.

Avila, F. J. R. \& Preiss, A. (2015). Strategic Management: A Survival Need for Mexican SMEs. Business Management and Strategy, 6(1), doi: https://doi.org/10.5296/bms.v6i1.7481.

Baglivo, J., Olivier, D., \& Pagano, M. (1988). Methods for the analysis of contingency tables with large and small cell counts. Journal of the American Statistical Association, 83(404), 1006-1013. doi:10.1080/01621459.1988.10478692.

Barnes, B.R., Leonidou, L.C., Siu, N.Y.M., \& Leonidou, C. (2010). Opportunism as the inhibiting trigger for developing long-term-oriented Western exporter - Hong Kong importer relationships. Journal of International Marketing, 18(2), 35-64.

Barroso, J.M.D. (2013). Speech by President Barroso on the outcome of the European Council meeting on the Multiannual Financial Framework of 7-8 February 2013. Retrieved from http://europa.eu/rapid/press-release_SPEECH-13-130_en.htm.

Belas, J., Gavurova, B., Kubalek, J., Kubak, M. (2020). Discrepancies in Perception and Evaluation of Macroenvironment - Sectoral Analysis. Journal of Business Economics and Management, 21(4), 1072-1092. doi: 10.3846/jbem.2020.12274. 
Bembenek, B. \& Kowalska, K. (2016). SMEs development within industrial clusters strategic challenge for cluster management. Modern Management Review, 23(4). doi: 10.7862/rz.2016.mmr.41.

Bingöl, D., Filizöz, B., Koparan, E., Okan, T. \& Çapkulaç, O. (2017). The effect of the strategic management tools on SME's firm performance. ISMC 2017. 13th International Strategic Management Conference, pp. 352-362, http://dx.doi.org/10.15405/epsbs.2017.12.02.30.

Bratianu, C. (2011a). Changing paradigm for knowledge metaphors from dynamics to thermodynamics. System Research and Behavioral Science, 28, 160-169.

Bratianu, C. (2011b). A new perspective of the intellectual capital dynamics in organizations. In Vallejo-Alonso, B., Rodriguez-Castellanos, A., Arregui-Ayastuy, G. (Eds.). Identifying, measuring, and valuing knowledge-based intangible assets: new perspectives (pp. 1-21). Hershey, PA: IGI Global.

Bratianu, C. (2013). The triple helix of the organizational knowledge. Management Dynamics in the Knowledge Economy, 1(2013), 207-220.

Dima, M.A, Ghinea, V (2016). A model of Academic Leadership, Book Series: Proceedings of the Conference on European Management Leadership and Governance, 12th European Conference on Management, Leadership and Governance (ECMLG), Natl Univ Polit.

Dincă, V. M., Dima, A. M., \& Rozsa, Z. (2019). Determinants of cloud computing adoption by Romanian SMEs in the digital economy. Journal of Business Economics and Management, 20(4), 798-820. https://doi.org/10.3846/jbem.2019.9856Studies \& Publ Adm, Coll Management, Bucharest, pp. 61-7.

Dvorský, J., Petráková, Z., \& Polách, J. (2019). Assessing the Market, Financial, and Economic Risk Sources by Czech and Slovak SMEs. International Journal of Entrepreneurial Knowledge, 7(2), 30-40. doi: https://doi.org/10.37335/ijek.v7i2.91.

Edun, O. \& Wei, L. (2011). Knowledge Management and Innovation for Firms Competitiveness: A Strategic Approach for African SMEs. International Conference on Management and Service Science, Wuhan, 2011, pp. 1-5, doi: 10.1109/ICMSS.2011.5998937.

Entrialgo, M., Fernández, E. \& Vázquez, C. J. (2000). Linking entrepreneurship and strategic management: evidence from Spanish SMEs. Technovation, 20(8), 427-436. https://doi.org/10.1016/S0166-4972(99)00168-6.

Hosmane, B. S. (1986). Improved likelihood ratio tests and pearson chi-square tests for independence in two dimensional contingency tables. Communications in Statistics Theory and Methods, 15(6), 1875-1888. doi:10.1080/03610928608829224.

Ik, M. \& Azeez, A. A. (2020). Organisational green behavioural change: The role of Change Management. International Journal of Entrepreneurial Knowledge, 8(1), 34-48. doi: 10.37335/ijek.v8i2.98.

Ivanova, A. S., Holionko, N. G., Tverdushka, T. B., Olejarz, T., \& Yakymchuk, A. Y. (2019). The Strategic Management in Terms of an Enterprise's Technological Development. Journal of Competitiveness, 11(4), 40-56. https://doi.org/10.7441/joc.2019.04.03.

Jones, R. \& Sisay, S. (2014). Handbook of Research on Strategic Management in Small and Medium Enterprises, 21. doi: 10.4018/978-1-4666-5962-9.ch00.

Khan, K.A., Çera, G., \& Nétek, V. (2019). Perception of the Selected Business Environment Aspects by Service Firms. Journal of Tourism and Services, 10(19), 111-127, https://doi.org/10.29036/jots.v10i19.115. 
Matijová, M., Onuferová, E., Rigelský, E., \& Stanko, V. (2019). Impact of Selected Indicators of Tourism Capacity and Performance in the Context of the Unemployment Rate in Slovakia. Journal of Tourism and Services, 10(19), 1-23. https://doi.org/10.29036/jots.v10i19.95

Megyesiova, S., Lieskovska, V. (2018). Analysis of the Sustainable Development Indicators in the OECD Countries. Sustainability, 10(12), 4554. doi: 10.3390/su10124554.

Miladi, A. I. (2014). Governance for SMEs: Influence of leader on organizational culture. International Strategic Management Review, 2(1), 21-30. https://doi.org/10.1016/j.ism.2014.03.002.

Milshina, Y. \& Vishnevskiy, K. (2016). Potentials of collaborative foresight for SMEs. Technology Analysis \& Strategic Management, 30(6), 701-717. https://doi.org/10.1080/09537325.2017.1406906.

Novák Sedláčková, A., Švecová, D., \& Tomová, A. (2019). Slovak Airports As Profit/Loss Making Entities: Consequences For Transport Policies. Journal of Tourism and Services, 10(19), 153-163. https://doi.org/10.29036/jots.v10i19.112

Oladimeji, M. S. \& Udosen, I. (2019). The Effect of Diversification Strategy on Organizational Performance. Journal of Competitiveness, 11(4), 120-131. https://doi.org/10.7441/joc.2019.04.08.

Oluyede, B. O. (1994). A modified chi-square test of independence against a class of ordered alternatives in an r x c contingency table. Canadian Journal of Statistics, 22(1), 75-87. doi:10.2307/3315824.

Pasanen, M. (2011). Strategic Management Tools and Techniques in Smes (June 20, 2011). Society of Interdisciplinary Business Research (SIBR) 2011 Conference on Interdisciplinary Business Research. http://dx.doi.org/10.2139/ssrn.1867897.

Srovnalíková, P., Semionovaitè, E., Baranskaitè, E., \& Labanauskaitè, D. (2020). Evaluation of the Impact of Sharing Economy on Hotel Business. Journal of Tourism and Services, 20(11), 150-169. doi: 10.29036/jots.v11i20.145.

Stonehouse, G. \& Pemberton, J. (2002). Strategic planning in SMEs - some empirical findings. Management Decision, 40(9), 853-861. https://doi.org/10.1108/00251740210441072.

Subic, J., Vasiljevic, Z., \& Andrei, J. (2010). The impact of FDI on the European economic development in the context of diversification of capital flows. Proceedings of the 14th International Business Information Management Association, Business Transformation through Innovation and Knowledge Management: An Academic Perspective, Istanbul, Turkey, 23-24.

Šumpíková, M. \& Ďurčeková, I. (2019). Transaction Costs, Outsourcing, and the Public Procurement Review Process in the Czech Republic and Slovakia. NISPAcee Journal of Public Administration and Policy, 12(2). doi: https://doi.org/10.2478/nispa-2019-0021. Tacogliu, C., Ceylan, C., \& Kazancoglu, Y. (2019). Analysis of Variables Affecting Competitiveness of SMEs in the Textile Industry. Journal of Business Economics and Management, 20(4), 648-673. https://doi.org/10.3846/jbem.2019.9853.

Verbano, Ch. \& Crema, M. (2014). Linking technology innovation strategy, intellectual capital and technology innovation performance in manufacturing SMEs. Technology Analysis \& Strategic Management, 28(5), 524-540, https://doi.org/10.1080/09537325.2015.1117066. 